\title{
Autoantibodies against Heat Shock Protein 60 Mediate Endothelial Cytotoxicity
}

\author{
Georg Schett, ${ }^{\star *}$ Qingbo Xu, * Albert Amberger, * Ruurd Van der Zee," Heidrun Recheis, ${ }^{\ddagger}$ Johann Willeit, $\$$ and \\ Georg Wick* \\ *Institute for Biomedical Aging Research, Austrian Academy of Sciences, A-6020 Innsbruck; ${ }^{\ddagger}$ Institute for General and Experimental \\ Pathology and ${ }^{8}$ Clinic of Neurology, University of Innsbruck, Medical School, A-6020 Innsbruck, Austria; and "Institute of Infectious \\ Diseases and Immunology, Faculty of Veterinary Medicine, 3508TD Utrecht, The Netherlands
}

\begin{abstract}
Stress or heat shock proteins (hsp) are a family of approximately two dozen proteins with a high degree of amino acid sequence homology between different species, ranging from prokaryotes to humans, and are representative of a generalized response to environmental and metabolic stressors. Our previous studies showed increased expression of human hsp60 on endothelial cells of arterial intima with atherosclerotic lesions, and elevated levels of serum antibodies $(\mathrm{Ab})$ against hsp65/60 in subjects with carotid atherosclerosis. To investigate the possible involvement of anti-hsp65/60 Ab in endothelial injury, specific hsp-Ab were isolated from human high titer sera by affinity chromatography and probed on heat-shocked human umbilical vein endothelial cells. Purified human anti-hsp65/60 Ab reacted specifically with mycobacterial hsp65, human hsp60, and a 60-kD protein band of heat-shocked endothelial cells. High levels of hsp60 mRNA expression in endothelial cells were found between 4 and $12 \mathrm{~h}$ after 30 min treatment at $42^{\circ} \mathrm{C}$. In immunofluorescence tests, positive staining of heat-stressed endothelial cells was observed not only in the cytoplasm but also on the cell surface. Furthermore, only heat-stressed, but not untreated, ${ }^{51} \mathrm{Cr}$-labeled endothelial cells were lysed by antihsp65/60 Ab in the presence of complement (complementmediated cytotoxicity) or peripheral blood mononuclear cells (antibody-dependent cellular cytotoxicity). Control Abs, including human anti-hsp65/60 low titer antiserum, human Ig fraction deprived of hsp65/60 Ab, and mAbs to Factor VII, $\alpha$-actin, hsp70, and CD3 showed no cytotoxic effect. In conclusion, human serum anti-hsp65 antibodies act as autoantibodies reacting with hsp60 on stressed endothelial cells and are able to mediate endothelial cytotoxicity. Thus, a humoral immune reaction to hsp60 may play an important role in the pathogenesis of atherosclerosis. (J. Clin. Invest. 1995.96:2569-2577.) Key words: heat shock proteins • autoantibodies • atherosclerosis • endothelial cells - cytotoxicity
\end{abstract}

\section{Introduction}

In response to localized injury, e.g., high temperature, mechanical stress, infections, surgical stress, oxidants, and cytokine

Address correspondence to Georg Wick, Institute for Biomedical Aging Research, Austrian Academy of Sciences, Rennweg 10, A-6020 Innsbruck, Austria. Phone: 43-512-583-9190; Fax: 43-512-583-9198.

Received for publication 6 March 1995 and accepted in revised form 24 August 1995.

J. Clin. Invest.

(C) The American Society for Clinical Investigation, Inc.

0021-9738/95/12/2569/09 \$2.00

Volume 96, December 1995, 2569-2577 stimulation, cells produce high levels of heat shock protein (hsp $)^{1}$ to protect themselves against these unfavorable conditions (1-3). Endothelium, as a barrier between blood and underlying cells of the vessel wall, is subjected to various stresses that evoke hsp expression. We have shown previously that aortic endothelial cells express high levels of hsp60 not only in the cytoplasm but also on the cell surface when treated with high temperature or TNF- $\alpha$ and labeled with a panel of mAbs against various epitopes of hsp60. This surface staining was only observed using an $\mathrm{mAb}$ recognizing an epitope present in a portion of the 575 amino acid-long hsp60 comprising residues 288366 (4). Furthermore, we also found elevated hsp60 expression on aortic endothelial cells in response to other types of stress, such as bacterial endotoxin or hydrogen peroxide (Seitz, C., R. Kleindienst, Q. Xu, and G. Wick, manuscript submitted for publication). In atherosclerotic lesions of rabbits and humans, endothelial cells again showed much higher levels of hsp60 compared to those in normal arterial intima, supporting the concept of a possible involvement of hsp60 in the development of atherosclerosis $(5,6)$. As a matter of fact, immunization of rabbits with recombinant mycobacterial hsp65 induced the development of atherosclerotic lesions at characteristic predilection sites known to be subject to increased hemodynamic stress, such as the aortic and the branching of large vessels (7).

A previous epidemiological study (8) from our laboratory had demonstrated that serum antibodies to mycobacterial hsp65, which is a homologue of human hsp60, were significantly increased in clinically healthy subjects with sonographically demonstrable carotid atherosclerosis compared to those without lesions. This increased antibody level was independent of other established risk factors, such as hyperlipidemia, smoking, hypertension, diabetes mellitus, and obesity, thus providing evidence for a strong correlation of hsp65 antibodies with carotid atherosclerosis. These serum antibodies cross-reacted with recombinant human hsp60 homologue, and also with homogenates of atherosclerotic lesions both showing a $60-\mathrm{kD}$ protein band on Western blots (9). Double-immunofluorescence labeling of atherosclerotic lesions with human anti-hsp65 sera and cell marker-specific antibodies demonstrated expression of hsp60 by endothelial cells, as well as by macrophages and smooth muscle cells therein. These findings indicated the existence of serum antibodies reacting not only with mycobacterial hsp65 but also with mammalian hsp60, expressed as an autologous cellular component $(6,9)$.

Based on these observations we next addressed the question whether human anti-hsp65/60 antibody $(\mathrm{Ab})$ from high titer sera could react with surface proteins, e.g., hsp60 on stressed endothelial cells, and whether these antibodies could mediate

\footnotetext{
1. Abbreviations used in this paper: $\mathrm{ADCC}$, antibody-dependent cellular cytotoxicity; hsp, heat shock protein.
} 
Table I. Characteristics of Blood Donors

\begin{tabular}{|c|c|c|c|c|}
\hline No. & Sex & Age & Lesion score & hsp65-Ab titers \\
\hline \multicolumn{5}{|c|}{$y r$} \\
\hline 1 & Male & 74 & 1.89 & $1: 1,280$ \\
\hline 2 & Female & 72 & 2.14 & $1: 2,560$ \\
\hline 3 & Male & 65 & 3.31 & $1: 1,280$ \\
\hline 4 & Female & 78 & 4.42 & $1: 1,280$ \\
\hline 5 & Male & 66 & 2.53 & $1: 2,560$ \\
\hline 6 & Male & 75 & 3.18 & $1: 2,560$ \\
\hline 7 & Female & 67 & 1.56 & $1: 1,280$ \\
\hline 8 & Female & 69 & 1.67 & $1: 1,280$ \\
\hline 9 & Male & 72 & 4.32 & $1: 2,560$ \\
\hline 10 & Male & 69 & 2.45 & $1: 1,280$ \\
\hline 11 & Female & 79 & 0.0 & $1: 20$ \\
\hline 12 & Male & 75 & 0.0 & $1: 10$ \\
\hline 13 & Female & 70 & 0.0 & $1: 10$ \\
\hline 14 & Male & 66 & 0.0 & $1: 20$ \\
\hline 15 & Male & 68 & 0.0 & $1: 40$ \\
\hline 16 & Female & 72 & 0.0 & $1: 80$ \\
\hline 17 & Female & 77 & 0.0 & $1: 20$ \\
\hline 18 & Male & 68 & 0.0 & $1: 20$ \\
\hline 19 & Female & 67 & 0.0 & $1: 40$ \\
\hline 20 & Male & 78 & 0.0 & $1: 10$ \\
\hline \multicolumn{4}{|c|}{ High titer serum pool } & $1: 1,280$ \\
\hline \multicolumn{4}{|c|}{ Low titer serum pool } & $1: 20$ \\
\hline \multicolumn{4}{|c|}{ Purified anti-hsp65/60 antibodies } & $1: 640$ \\
\hline \multicolumn{4}{|c|}{ Unbound Ig fraction } & $<1: 10$ \\
\hline \multicolumn{5}{|c|}{$\begin{array}{l}\text { mAbs (anti-Factor VIII-, anti- } \alpha \text {-actin-, anti- } \\
\text { hsp70-, anti-CD3) }\end{array}$} \\
\hline \multicolumn{4}{|c|}{ Guinea pig serum (source of complement) } & $<1: 10$ \\
\hline
\end{tabular}

Two groups of sera were selected from 867 clinically healthy blood donors (7) according to scores of carotid atherosclerotic lesions (0-9.2) measured by sonography and serum antibody titers as detailed elsewhere (7). hsp65/60 Abs were determined with an ELISA.

endothelial cytotoxicity. In the present study, hsp65/60 specific antibodies were isolated from human sera and tested for their lytic potential on temperature-stressed human umbilical vein endothelial cells. The interaction of the antibodies with stressed endothelial cells was investigated using immunofluorescence and isotope labeling techniques.

\section{Methods}

Characteristics of blood donors and antibody determination. 20 samples of human sera, divided into two groups, were selected according their anti-hsp serum antibody titers and the occurrence of atherosclerotic lesions in carotid arteries from 867 subjects investigated in a previous study (reference 8 , Table I). The methods for determination of carotid atherosclerotic lesions and serum antibodies have been described elsewhere (8). Briefly, both common carotid arteries were sonographically assessed by physician specialists with high resolution duplex scanning equipment (ATL UM8; Advanced Technology Laboratories, Bethol, WA) using a Biosound compact real-time (B-mode) imager with a 10$\mathrm{MHz}$ sector scanner probe and digital scan convertor. Lesions were quantified with a sensitive and reproducible plaque scoring system encompassing 16 different measurements, each of which represented the maximum axial diameter of atherosclerotic lesions on the near or far wall at eight well-defined imaging sites. An ELISA was used to identify hsp65 antibodies. Recombinant hsp65 ( $1 \mu \mathrm{g} / \mathrm{ml}$, a gift from Dr. J. D. A. van Embden, National Institute of Public Health and Environmental Protection, The Netherlands) was coated onto the wells of 96-well flatbottomed ELISA plates (11041E; Petra-Plastic, Würzburg, Germany) overnight at $4^{\circ} \mathrm{C}$. After washing with PBS, pH 7.2, supplemented with Tween $20(0.05 \%$, vol/vol ) and blocking with 1\% BSA (H3311; Sigma Chemical Co., Munich, Germany) in PBS, $100 \mu$ l of human serum was added in appropriate dilutions. Conjugated horseradish peroxidase rabbit anti-human Ig (P217; Dakopatts, Glostrup, Denmark) was used, and the reaction visualized with the substrate $2,2^{\prime}$-azino-bis 3-ethylbenzthiazoline-6-sulfonic acid (Sigma Chemical Co.). Absorbance was measured at $410 \mathrm{~nm}$ with a Microelisa Autoreader (Dynatech Laboratories Inc., Chantilly, VA).

Affinity chromatography isolation of hsp65/60 antibodies. The hsp65 coupling was performed using Affi-Gel 15 kit (153-6051; BioRad Laboratories, Hercules, CA) according to the manufacturer's recommendations. Briefly, recombinant mycobacterial hsp65 solubilized in Hepes buffer $(0.1 \mathrm{M})$ were incubated with the gel $(1 \mathrm{ml})$ under constant gentle agitation for $4 \mathrm{~h}$ at $4^{\circ} \mathrm{C}$. Thereafter, $100 \mu$ l of ethanolamine- $\mathrm{HCl}$ ( $1 \mathrm{M}, \mathrm{pH} 8.0$ ) was added and the gel was incubated for another hour to block protein binding activity. The coupled gel was transferred to the column, washed with Hepes buffer, and equilibrated with PBS, $\mathrm{pH} 7.2$.

Pooled human anti-hsp65 high titer sera were inactivated at $56^{\circ} \mathrm{C}$ for $30 \mathrm{~min}$ and precipitated with $50 \%$-saturated $\left(\mathrm{NH}_{4}\right)_{2} \mathrm{SO}_{4}$. The precipitated Igs $(5 \mathrm{mg} / \mathrm{ml})$, dialyzed against PBS overnight, were added to the column, incubated $30 \mathrm{~min}$ at room temperature, and washed to remove unbound material monitoring with OD $280 \mathrm{~nm}$. This unbound Ig fraction (free of anti-hsp65/60 Ab) was dialyzed, filtered, and used as a negative control. When no more proteins were detectable in the effluent, $6 \mathrm{ml} 20-\mathrm{mM} \mathrm{HCl}$ was added. The eluant was fractionated in $300-\mu l$ portions and immediately neutralized with $0.5 \mathrm{M} \mathrm{NaOH}$. Fractions with an OD value over $0.25 \mathrm{~nm}$ were pooled, concentrated, dialyzed against medium 199 (T06110; Seromed, Berlin, Germany), and filtered. This entire procedure was repeated five times, and $3.3 \mathrm{mg}$ of Ig was thus obtained from $12 \mathrm{ml}$ of original high titer serum. Antihsp65 reactivity of the purified Ab, measured by the ELISA described above, was similar to that of the original high titer serum (Table I).

Classes of isolated Igs were determined in radial immunodiffusion and measured with a precipitation reader (Behringwerke Ag, Marburg, Germany).

Endothelial cell culture. Human umbilical cords were obtained from the Clinic of Gynecology and Obstetrics, University of Innsbruck, Medical School, and the vein was dissected and rinsed four times with icecold medium 199 to remove blood cells. Human umbilical vein endothelial cells were dissociated by collagenase (type IV, $2.5 \mathrm{mg} / \mathrm{ml}, \mathrm{C} 5138$; Sigma Chemical Co.) for $20 \mathrm{~min}$ at room temperature. After washing with medium 199, the cells were seeded onto six-well plates (3064; Falcon Labware, Becton Dickinson \& Co., Oxnard, CA) precoated with $0.2 \%$ gelatin (G1393; Sigma Chemical Co.) in medium 199 supplemented with $15 \%$ inactivated FCS (Seromed), $100 \mu \mathrm{g} / \mathrm{ml}$ heparin (H8514, Sigma), $100 \mu \mathrm{g} / \mathrm{ml}$ endothelial cell growth supplement (E0760; Sigma), $10 \mathrm{mM}$ Hepes (03025; Seromed), $100 \mathrm{U} / \mathrm{ml}$ penicillin and $100 \mu \mathrm{g} / \mathrm{ml}$ streptomycin. For subculture, confluent cells were dissociated from the plates by $0.2 \%$ trypsin $/ 0.1 \%$ EDTA (T6539; Sigma) and cultivated in either 96-well plates or 25-ml flasks (Falcon Labware). Endothelial cells were identified by morphology and immunofluorescence staining with antibodies to Factor VIII (M616; Dakopatts) (10). Two to four passages were used for all experiments.

RNA isolation and Northern blots. Total RNA was isolated following a standard protocol, as described earlier (11). RNA (10 $\mu \mathrm{g} /$ lane) was denatured with formaldehyde (Merck, Darmstadt, Germany), electrophoresed in a $1 \%$ agarose gel and transferred onto a nylon membrane (zeta Probe; Bio-Rad Laboratories, Richmond, CA). RNA was UV cross-linked in a UV Stratalinker (Stratagene Inc., La Jolla, CA) and hybridized with the ${ }^{32} \mathrm{P}$-labeled probe (BamHI-EcoRI fragment of human hsp60 gene; clone pSJ60 was a gift from S. Jindal, PerSeptive 
Table II. Ig Classes of Purified Anti-hsp65/60 Antibodies

\begin{tabular}{lccc}
\hline Classes & Normal serum* & Pooled hsp65 antiserum & Purified Abs \\
\hline IgA & $9.7-17.9$ & 8.7 & 30.3 \\
IgG & $70.8-83.5$ & 86.2 & 40.2 \\
IgM & $6.8-11.3$ & 4.7 & 29.5
\end{tabular}

IgA, IgG, and IgM were determined by radial immunodiffusion and calculated against standard. * Values for Ig classes in normal human serum from the Diagnostic Laboratory of the Immunopathology Unit of the Institute for General and Experimental Pathology, University of Innsbruck, Medical School.

Biosystems, Cambridge, MA) and glycerylaldehyde-3 phosphate dehydrogenase $(\mathrm{GAPDH}$, reference 12$)$ at $65^{\circ} \mathrm{C}$. The filters were then washed and exposed to Kodak XAR films (Eastman Kodak Co., Rochester, $\mathrm{NY})$ at $-80^{\circ} \mathrm{C}$.

Western blotting. Confluent endothelial cells $\left(5 \times 10^{6}\right)$ remained at $37^{\circ} \mathrm{C}$ or were incubated at $42^{\circ} \mathrm{C}$ for $30 \mathrm{~min}$ and subsequently at $37^{\circ} \mathrm{C}$ for another $3 \mathrm{~h}$. After three washes with PBS, cells were collected with a rubber policeman and pelleted by centrifugation at $1,200 \mathrm{~g}$ for 10 min. $200 \mu$ l of lysis buffer containing $0.15 \mathrm{M} \mathrm{NaCl}, 50 \mathrm{mM}$ Tris, $1 \mathrm{mM}$ EDTA, 0.05\% SDS, $0.5 \%$ Triton X-100, and $1 \mathrm{mM} \mathrm{PMSF,} \mathrm{pH} \mathrm{7.4,}$ were added. After $1 \mathrm{~h}$ of incubation at room temperature, the cell lysate was centrifuged at $5,000 \mathrm{~g}$ for $10 \mathrm{~min}$. The supernatant was harvested and the protein content measured with a protein assay kit (500-0006; Bio-Rad Laboratories, Hercules, CA $)$. Cell proteins $(50 \mu \mathrm{g})$ were diluted 1:2 ( $\mathrm{vol} / \mathrm{vol})$ with electrophoresis sample buffer $(5 \% \beta$-mercaptoethanol, $15 \%$ glycerol, $3 \%$ SDS, $0.1 \mathrm{M}$ Tris, pH 6.8). Samples, including recombinant human hsp60 (derived from clone PKK 13A; reference 13), mycobacterial hsp65, and endothelial cell proteins, were resolved on $12 \%$ polyacrylamide gels under reducing conditions (14). Proteins were electrophoretically blotted onto nitrocellulose membranes (BA85; Schleicher und Schuell, Dassel, Germany) in $25 \mathrm{mM}$ Tris, $192 \mathrm{mM}$ glycine, $20 \%$ methanol, $\mathrm{pH} 8.3$, at $100 \mathrm{~mA}$ for $16 \mathrm{~h}$. After blocking with $1 \%$ BSA-PBS for $1 \mathrm{~h}$ and for another hour with $3 \%$ nonfat dry milk (Sigma), the blots were probed with the affinity-purified human anti-hsp65/60 antibodies (50 ng/ml PBS supplemented with 1\% BSA) or human high titer serum (diluted 1:500 vol/vol) for $5 \mathrm{~h}$. The reaction was visualized using horseradish peroxidase-conjugated rabbit antihuman Ig secondary antibodies (Z259; Dakopatts), diluted 1:400 followed by addition of 4-chloro-1-naphthol/hydrogen peroxide (Sigma).

Immunofluorescence. Immunofluorescence studies were performed as described (4) with slight modifications. Subconfluent endothelial cells in eight-well slide chambers (177445; Nunc Inc., Naperville, IL) were incubated at $42^{\circ} \mathrm{C}$ for $30 \mathrm{~min}$, and then at $37^{\circ} \mathrm{C}$ for $3 \mathrm{~h}$. For surface staining, cells were washed two times with PBS and incubated with 200 $\mu \mathrm{l}$ of the human anti-hsp65/60 Ab for $1 \mathrm{~h}$ at room temperature. After three washes with PBS, the cells were incubated with a rabbit antihuman Ig-FITC conjugate (F200; Dakopatts) for $30 \mathrm{~min}$, fixed with absolute methanol for $5 \mathrm{~min}$, rinsed, and embedded in $n$-propylgalat/ glycerol (P3130; Sigma). For cytoplasmic staining, cells were air dried and permeabilized with 5\% acetic acid/methanol for $5 \mathrm{~min}$ followed by the treatment described above. The slides were examined in a laser confocal microscope (Carl Zeiss Inc., Thornwood, NY) as described previously (15).

Cytotoxicity assay. For complement-mediated cytotoxicity, endothelial cells $\left(3 \times 10^{4} /\right.$ well $)$ in 96 -well flat-bottomed plates (3072; Falcon Labware) were stressed at $42^{\circ} \mathrm{C}$ for $30 \mathrm{~min}$ and then kept at $37^{\circ} \mathrm{C}$ for another $90 \mathrm{~min}$, or only cultured at $37^{\circ} \mathrm{C}$ for $120 \mathrm{~min}$ and labeled with $100 \mu \mathrm{l}$ of $10 \%$ FCS containing $5 \mu \mathrm{Ci}{ }^{51} \mathrm{Cr}$ (Behringwerke) for the last $90 \mathrm{~min}$ at $37^{\circ} \mathrm{C}$. After three washes with medium $199,100 \mu \mathrm{l}$ of diluted antibodies (dilution of anti-hsp65/60 Ab 1:10, high titer serum adjusted to same anti-hsp65/60 titer and control $\mathrm{Ab}$ to same protein concentration as anti-hsp65/60 Ab) were added and incubated for $7 \mathrm{~h}$ at $37^{\circ} \mathrm{C}$ in the

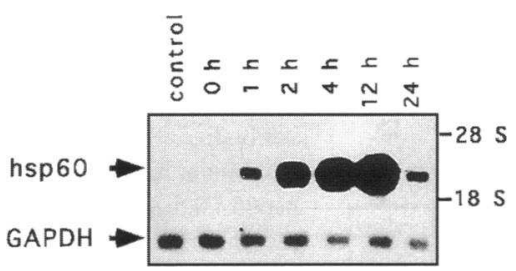

Figure 1. Hsp60 mRNA expression. Confluent endothelial cells were treated at $42^{\circ} \mathrm{C}$ for 30 min and then incubated at $37^{\circ} \mathrm{C}$. Total RNA was isolated from the cells at indicated times, and

Northern blotting was performed ( $10 \mu \mathrm{g}$ RNA/lane). Note the increase of hsp60 expression as compared to GAPDH from 1 to $12 \mathrm{~h}$.

presence of guinea pig serum ( $50 \mu \mathrm{l}, 1140$; Behringwerke) as source of complement. Guinea pig serum was selected to be free of anti-hsp65/ $60 \mathrm{Ab}$ (ELISA). At the end of the incubation period, $100 \mu \mathrm{l}$ of cold $\left(4^{\circ} \mathrm{C}\right) 10 \%$ FCS was added, the plates were centrifuged at $800 \mathrm{~g}$ for 10 $\min$ at $4^{\circ} \mathrm{C}$, and $150 \mu \mathrm{l}$ of supernatant was removed and radioactivity measured in a gamma counter (Wizzard Automatic Gamma Counter; Wallac, Helsinki, Finland)

To determine antibody-dependent cellular cytotoxicity (ADCC), PBMC were isolated from healthy donors by density centrifugation (Lymphoprep, density 1,077; Nycomed Pharmaceuticals Oslo, Norway) as described previously (16). In a procedure similar to that used to test antibody complement-mediated cytotoxicity, PBMC rather than complement were added as effector in 10\% FCS at various concentrations. In addition to low titer serum and unbound Ig fraction, four control antibodies, including mAb anti-human Factor VIII (M616; Dakopatts, Denmark), mAb anti-human $\alpha$-actin (1148818; Boehringer Mannheim, Mannheim, Germany), mAb anti-human hsp70 (SPA-810; StressGen Biotechnologies Corp., Victoria, Canada) and mAb anti-human CD3 Ab (M756, Dakopatts) were used in all experiments. Cell-specific release of radioactivity was calculated according to the formula: specific release $=$ (release in the presence of antibodies - spontaneous release $) /$ (maximal release - spontaneous release). Maximal release was represented by radioactivity in the presence of $1 \%$ Triton X-100; spontaneous release was determined by the addition of effectors to the culture in the absence of antibodies and did not exceed $15 \%$ of maximal release. To exclude any cytotoxic effect of heat stress, spontaneous releases were separately measured for stressed and unstressed cells and referred to an experimental release of stressed and unstressed cells, respectively. Antibody preparations alone were demonstrated not to be cytotoxic for stressed and unstressed cells. Statistical analysis was performed by a paired Student's $t$ test.

\section{Results}

We selected 20 blood donors with either high or low anti-hsp65 antibody titers from the 867 clinically asymptomatic subjects from our previous study (reference 8 , Table I) with or without sonographically detectable carotid atherosclerosis. These sera were used pooled or individually. Using affinity chromatography, $3.3 \mathrm{mg}$ of human Ig reacting with hsp65/60 was obtained, the composition of which is shown in Table II. The proportional distribution of Ig classes (IgA, IgG, and IgM) of total, unfractionated anti-hsp65/60 antisera was similar to that of normal serum, whereas anti-hsp65/60 Abs showed considerable differences. Although the relative majority of anti-hsp65/60 Abs were still of the IgG class, surprisingly, $40 \%$ of specific Abs were IgA and another $30 \%$ IgM.

Northern blots. To determine the time course of hsp60 expression by endothelial cells after 30 min treatment at $42^{\circ} \mathrm{C}$, mRNA was isolated from these cells at various times. The cells expressed hsp60 at $1 \mathrm{~h}$ after heat shock that increased to higher levels between 4 and $12 \mathrm{~h}$ (Fig. 1). Therefore, all further experiments in the present study were performed with endothelial cells within $12 \mathrm{~h}$ after heat shock. 


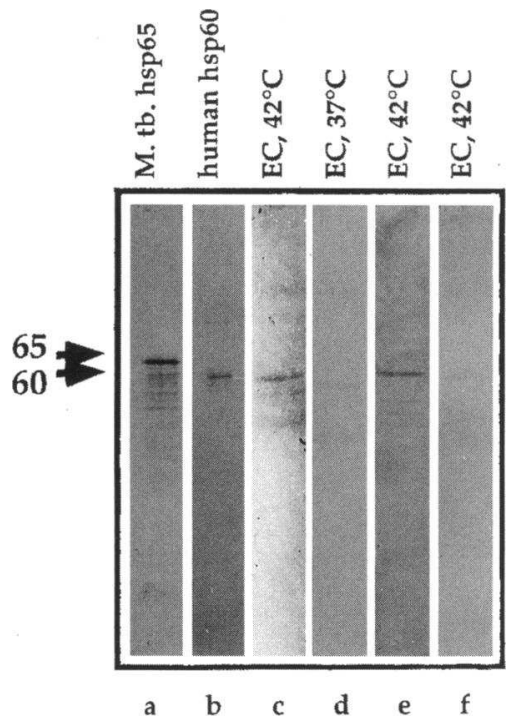

Figure 2. Examples of Western blots probed with human anti-hsp65 antibodies. Purified recombinant mycobacterial hsp65 (0.5 $\mu \mathrm{g}$, lane $a)$, recombinant human hsp60 ( $1 \mu \mathrm{g}$, lane $b)$, and total endothelial cell proteins $(50 \mu \mathrm{g}$, lanes $c-f)$ were separated on $12 \%$ SDS-PAGE gels followed by transfer to a nitrocellulose membrane. Blots were incubated with purified Abs against hsp65 (lanes $a-d$ ), antihsp65 high titer serum pool (lane $e$ ), or low titer serum pool (lane $f$ ) for $1 \mathrm{~h}$ at room temperature, and the reaction was visualized by 4-chloro-1-naphthol/ $\mathrm{H}_{2} \mathrm{O}_{2}$ after incubation with a peroxidase rabbit anti-human Ig conjugate. Note that a $60-\mathrm{kD}$ band was present in proteins of heat-treated endothelial cells probed with purified Abs or pooled high titer hsp65 antisera but not in proteins of untreated endothelial cells. M. tb., Mycobacterium tuberculosis; $E C$, endothelial cells.

Western blots. We have previously shown that human high titer sera reacted with mycobacterial hsp65 as well as human hsp60 (9). Using isolated Abs, we confirmed the cross-reactivity of these anti-hsp65 Ab with human hsp60 by immunoblotting (Fig. 2, lane $a$ and $b$ ). Furthermore, when endothelial cells were subjected to a heat stress at $42^{\circ} \mathrm{C}$ for $30 \mathrm{~min}$ and total cell proteins were separated on $12 \%$ polyacrylamide gel and analyzed in Western blot, a $60-\mathrm{kD}$ protein band was observed using purified hsp65/60 antibodies (Fig. 2, lane $c$ ) but not low titer antisera (lane $f$ ). Proteins derived from untreated endothelial cells showed very weak, if any, staining by anti-hsp65/60 Abs (Fig. 2, lane $d$ ), while a 60-kD band was found in heattreated cells probed with human anti-hsp65/60 high titer sera (Fig. 2, lane $e$ ).

Immunostaining. Localization of anti-hsp65/60 Ab reactivity in endothelial cells was visualized by indirect immunofluorescence. Strong cytoplasmatic staining resulted when subconfluent cells were heat treated, permeabilized by $5 \%$ acetic acid/ methanol fixation, and labeled with anti-hsp65/60 Ab or high titer sera (Fig. 3, $a$ and $c$ ). Untreated cells showed weaker cytoplasmatic staining with both pooled sera and anti-hsp65/ $60 \mathrm{Ab}$ (Fig. 3, $b$ and $d$ ), and no significant reaction was observed on heat-treated (Fig. $3 e$ ) or untreated cells (Fig. $3 f$ ) probed with pooled low titer sera. Interestingly, surface staining was found on living endothelial cells treated at $42^{\circ} \mathrm{C}$ and probed by both the high titer antisera and isolated Abs. This surface staining was clearly verified by confocal scanning laser microscopy (Fig. $4, a-h$ ). Very weak, if any, staining was seen either on untreated cells probed with high titer sera (Fig. $4 j$ ), antihsp65/60 Ab (Fig. $4 k$ ), or low titer sera (Fig. $4 l$ ), or heattreated cells probed with low titer sera (Fig. $4 i$ ). These results indicate that endothelial cells express at least certain epitopes of hsp60 recognized by polyclonal Abs on their membrane surface in response to heat shock, corroborating previous evidence using specific mAbs (4).
Complement-mediated cytotoxicity. Based on the observations described above, the cytotoxic potential of anti-hsp65/60 $\mathrm{Ab}$ was determined on confluent endothelial cells labeled with ${ }^{51} \mathrm{Cr}$. A specific dose-dependent release of radioactivity from heat-treated cells was found in the presence of anti-hsp65/60 antibodies or high titer serum and complement (Fig. 5). Comparing ${ }^{51} \mathrm{Cr}$ release of heat-treated and untreated cells revealed a significant difference $(P<0.01)$, although an average of $16 \%$ of total radioactivity was also released from untreated cells in the presence of the anti-hsp65/60 Ab (Fig. 6). ${ }^{51} \mathrm{Cr}$ release was only slightly above background when labeled cells were incubated with pooled low titer sera, unbound Ig-fraction, mAb anti-Factor VIII, mAb anti- $\alpha$-actin, mAb anti-hsp70, or mAb anti-CD3 (Fig. 6).

$A D C C$. To determine the potential of anti-hsp65/60 Ab to produce $A D C C$, heat-shocked and untreated endothelial cells were incubated with the anti-hsp65/60 Ab in the presence of normal human PBMC. Fig. 7 shows ${ }^{51} \mathrm{Cr}$ release at various effector-to-target ratios. Higher concentrations of effector cells, i.e., 50:1 and 100:1, entailed a significant degree of ADCC on heat-treated as compared to untreated cells $(P<0.01)$. More than $25 \%$ of total labeled ${ }^{51} \mathrm{Cr}$ was released from heat-treated endothelial cells by anti-hsp65/60 antibodies, while controls (low titer sera, unbound Ig-fraction, mAbs anti-Factor VIII, anti- $\alpha$-actin, anti-hsp70, or anti-CD3) induced $<8 \%$ of ${ }^{51} \mathrm{Cr}$ release from either stressed or unstressed cells (Fig. 8). Thus, anti-hsp65/60 antibodies or pooled high titer antisera were able to lyse endothelial cells in vitro via either complement-mediated cytotoxicity or ADCC.

\section{Discussion}

We have previously found that a large proportion of clinically healthy subjects with sonographically detectable carotid atherosclerosis have high levels of serum antibodies to mycobacterial hsp65 (8). These antibodies react not only with mycobacterial hsp65, but also with human hsp60, which is expressed in high concentrations in human atherosclerotic lesions (9). We now demonstrate that these antibodies react with a $60-\mathrm{kD}$ band protein of stressed endothelial cells and can mediate endothelial cytotoxicity, findings which could be significant for demonstrating the possible involvement of humoral immune reaction to hsp60 in the pathogenesis of atherosclerosis.

Accumulating evidence indicates that antibodies and complement are involved in atherogenesis (17-19). Muscari and co-workers (20) reported that serum IgA levels were significantly higher in patients with severe atherosclerosis. In the present study, we found that $>30 \%$ of total Ig isolated from antihsp65 antisera was IgA, although the significance of this phenomenon to the pathogenesis of atherosclerosis is still unclear. Furthermore, atherosclerotic lesions also contain Ig deposits not found in nonatherosclerotic arteries (21). Complement factors can be demonstrated with a similar tissue distribution, including the lytic C5b-9 complex (22-24), suggesting that complement activation occurs within the lesions (25). However, it is not yet clear which antigen(s) is responsible for these immune reactions, although oxidized LDL as antigens were found in atherosclerotic lesions (26-28). We now provide further evidence that hsp60 expressed at high levels on stressed endothelial cells may be a pathogenetically important autoantigen recognized by serum antibodies.

The in vitro phenomenon that anti-hsp65/60 serum antibod- 

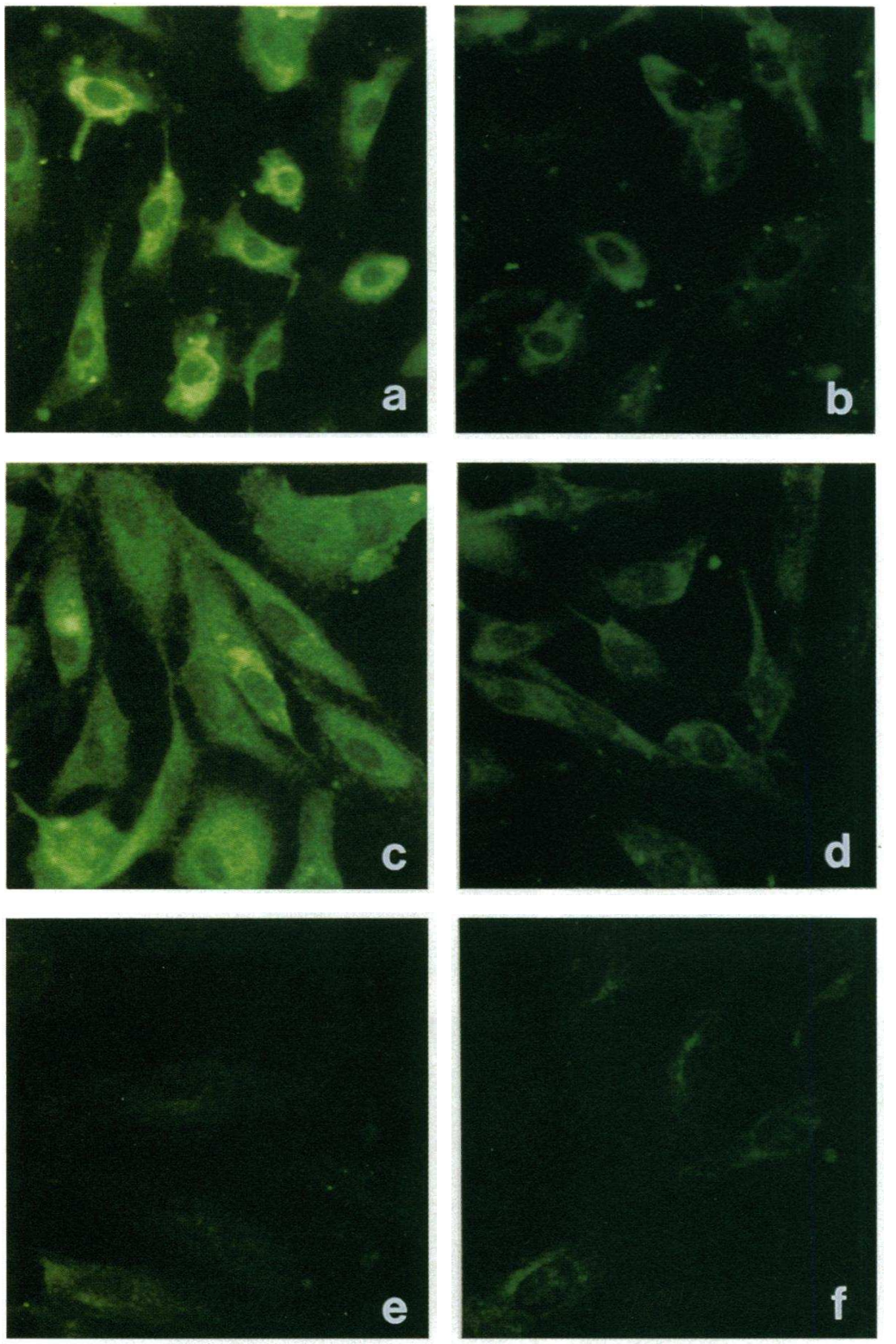

Figure 3. Indirect immunofluorescence staining of endothelial cells with anti-hsp65 antibodies. Subconfluent cells were incubated at $42^{\circ} \mathrm{C}$ for $30 \mathrm{~min}(a, c$, and $e$ ) followed by $3 \mathrm{~h}$ at $37^{\circ} \mathrm{C}$ or without heat stress $(b, d$, and $f)$. After three washes with medium 199, the cells were air dried, permeabilized by $5 \%$ acetic acid/methanol fixation, and probed with pooled high titer anti-hsp65 antisera ( $a$ and $b$ ), purified anti-hsp65 antibodies ( $c$ and $d$ ) or pooled low titer sera ( $e$ and $f$ ), visualized with a rabbit antihuman Ig-FITC, and examined with a laser confocal microscope $(\times 200)$. ies sometimes exerted a weak cytotoxic effect on unstressed endothelial cells may be explained by a low level of hsp60 expression on the surface of untreated cells being recognized by isolated antibodies, as documented in Figs. 3 and 4. hsp60 expression on untreated cells may be due to the fact that cells in culture are already subject to some stress compared to in vivo conditions. Although hsp60 is considered to be constitutively expressed in some cells, an inducible expression has been demonstrated in cells showing low basal levels of hsp60, including macrophages (29) and endothelial cells (4).

We have observed that surface expression of hsp60 occurs on aortic endothelial cells, e.g., when the cells from rat aortae were kept in culture and stained with various mAbs against hsp60. Positive staining of the endothelial cell surface was observed after stressing cells with high temperature, cytokinecontaining medium and TNF- $\alpha$, and labeling with a specific mAb, II-13 (4), directed against an epitope of amino acid residues 288-366 on hsp60, but not with another mAb, ML-30, recognizing the tetrapeptide epitope $315-318$ of this stress pro- tein (30). Hsp60 overexpression by endothelial cells may be an important response to various types of stress, including shear stress (31), in the course of physiological and pathological processes. On the other hand, although it is assumed that hsp are located in the cytoplasmic compartment to exert their function (32), evidence is emerging that surface expression of hsp60 in mononuclear cells may occur as well $(4,33,34)$. The exact transport mechanism of hsp60, or portions thereof, to the cell surface and the possible physiological role of this process still remain to be elucidated.

We also studied hsp60 expression in human atherosclerotic lesions (6) and detected hsp60 on endothelium and mononuclear cells of all carotid and aortic specimens, whereas smaller vessels, serving as reference specimens for normal intima without atherosclerotic lesions and mononuclear infiltration, showed no detectable expression of this stress protein. Interestingly, atherosclerotic lesions can be induced by immunization with mycobacterial hsp65 in normocholesterolemic rabbits (7). High concentration of hsp60 was found in the lesions induced either 

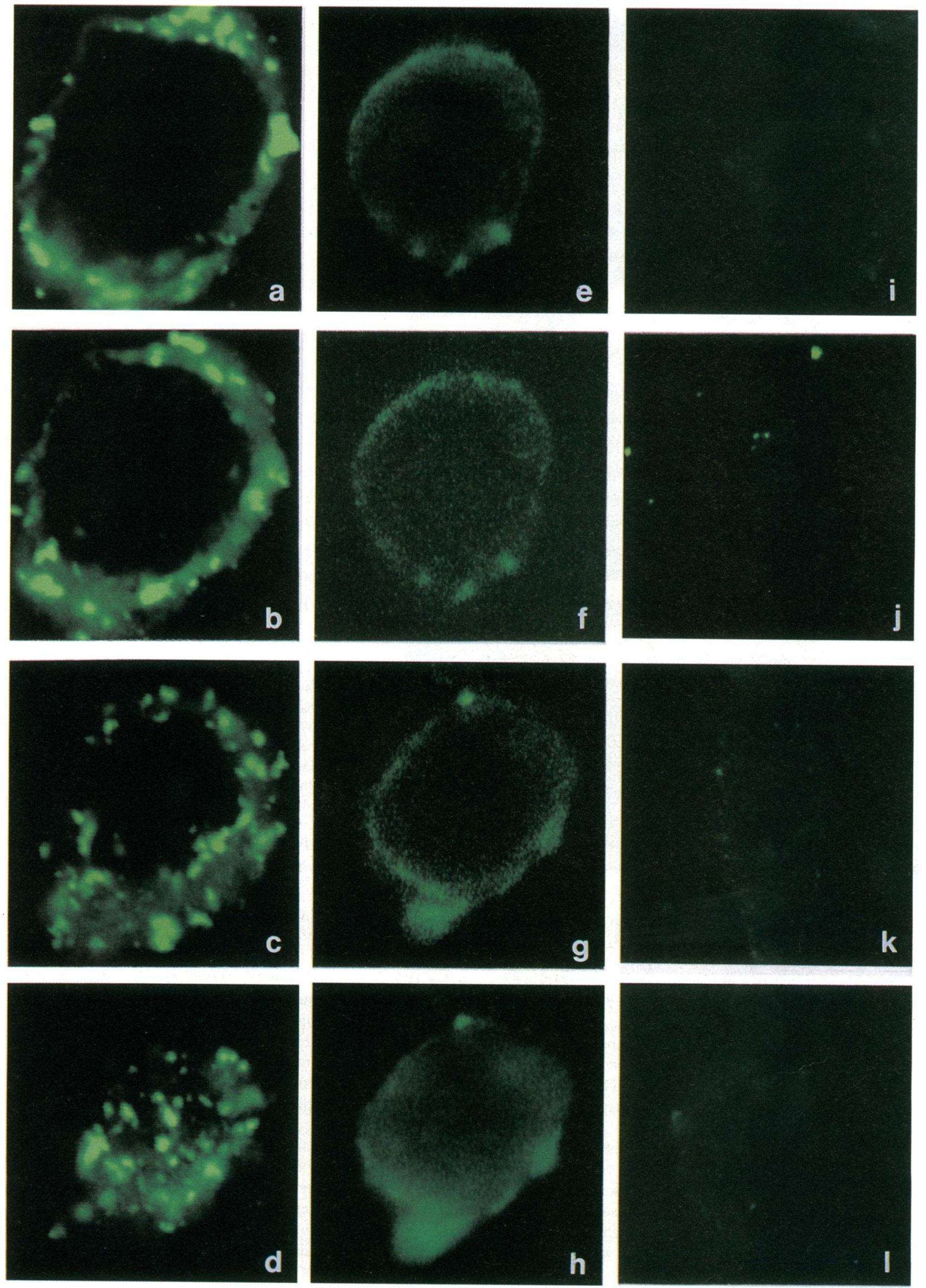


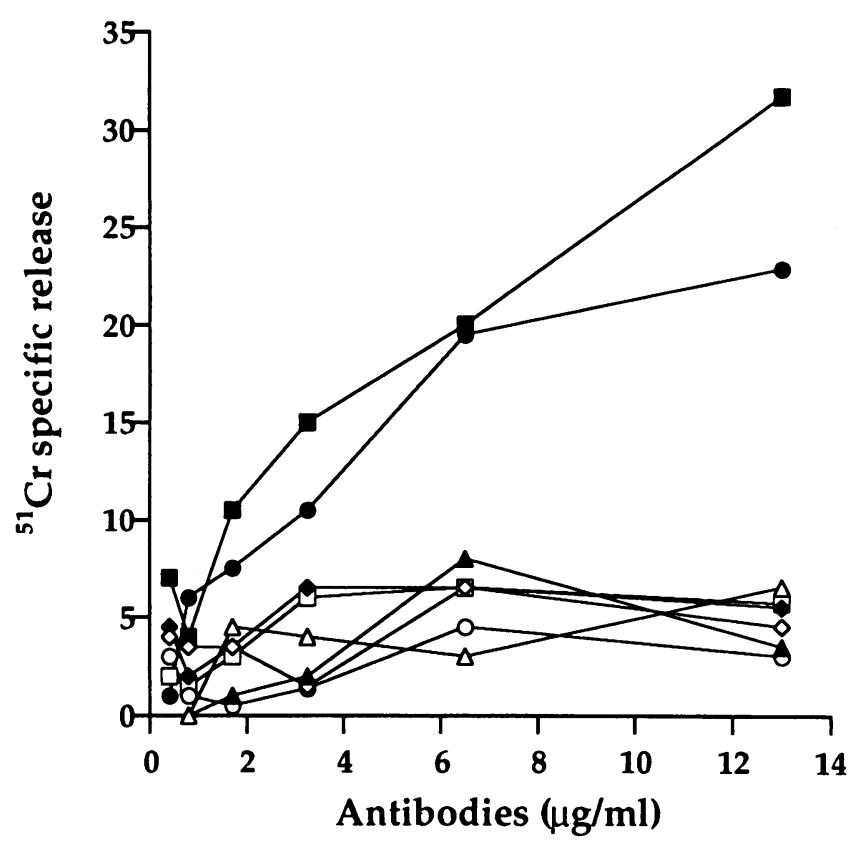

Figure 5. Dose-response curve of complement-mediated endothelial cytotoxicity. Confluent endothelial cells in 96-well plates were incubated at $42^{\circ} \mathrm{C}$ for $30 \mathrm{~min}$ followed by $90 \mathrm{~min}$ at $37^{\circ} \mathrm{C}$. After three washes with medium $199,5 \mu \mathrm{Ci}{ }^{51} \mathrm{Cr}$ in $100 \mu$ l of medium 199 containing $10 \%$ FCS was added to each well and incubated at $37^{\circ} \mathrm{C}$ for $1.5 \mathrm{~h}$. After two further washes, antibodies ( $\boldsymbol{a}$, pooled high titer antisera; $\bullet$, purified anti-hsp65 antibodies; $\square$, pooled low titer antisera; $O$, unbound Ig fraction; $\Delta, \mathrm{mAb}$ anti-Factor VIII; $\Delta, \mathrm{mAb}$ anti- $\alpha$-actin; $\bullet, \mathrm{mAb}$ antihsp70; and $\diamond, \mathrm{mAb}$ anti-CD3) at indicated concentrations in $100 \mu \mathrm{l}$ of medium were added, and incubated at $37^{\circ} \mathrm{C}$ for $7 \mathrm{~h}$ in the presence of guinea pig serum as a complement source. After incubation, supernatant radioactivity was determined in a gamma counter. The values are means of three experiments, each performed in triplicates.

by immunization or by administration of a $0.2 \%$ cholesterol diet (7). These findings are in contrast to reports which suggest a possible protective role of immune reactions to oxidized LDL on lesion formation (35). One important difference between the two mechanisms could lie in the different antigen distribution of oxidized LDL and hsp60. Hsp60 plays a predominant role as a cell-associated antigen, and its recognition by the immune system can thus entail cell damage, whereas in the case of oxidized LDL, considerable amounts of the antigen are found in the circulation $(36,37)$, allowing its binding to and elimination by $\mathrm{Ab}$ without a major effect on cells. Thus, the beneficial or harmful role, respectively, of immune reactions on atherogenesis possibly depends on the nature and physical state of the antigen that is predominantly targeted in each instance.

As mentioned above, serum hsp65/60 antibodies were significantly $(P<0.01)$ increased in clinically healthy subjects aged 40-79 yr with carotid atherosclerosis compared to those without lesions (8). Antibodies to hsp65/60 could be induced

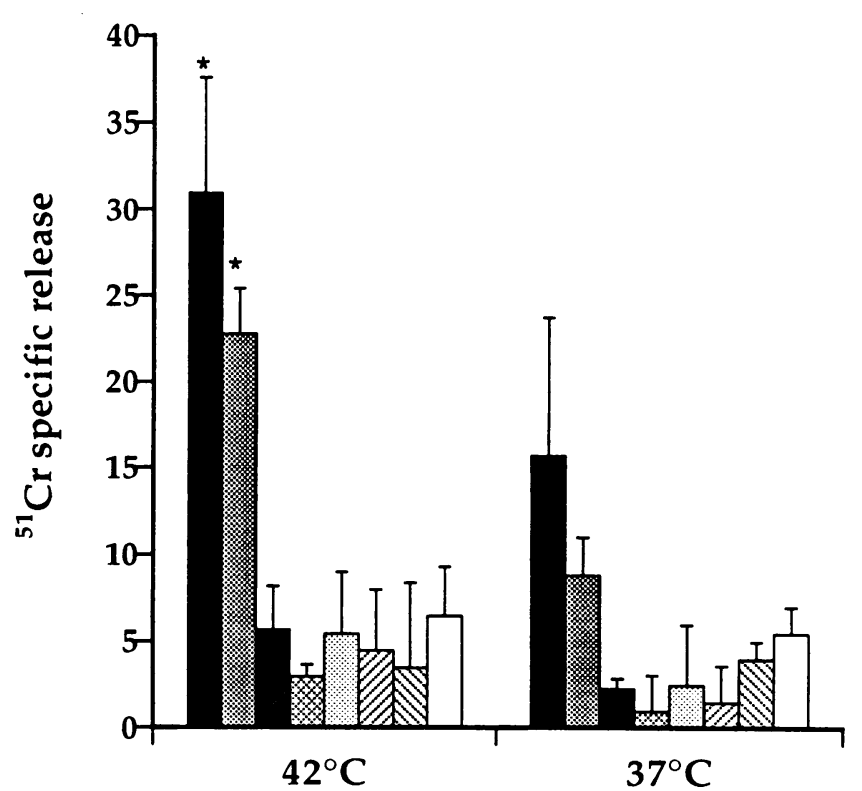

Figure 6. Comparison of complement-mediated cytotoxicity on heatstressed and unstressed endothelial cells. Confluent endothelial cells in 96-well plates were incubated at $42^{\circ} \mathrm{C}$ for $30 \mathrm{~min}$ followed by $90 \mathrm{~min}$ at $37^{\circ} \mathrm{C}$ or kept without treatment. After three washes with medium 199 , $5 \mu \mathrm{Ci}{ }^{51} \mathrm{Cr}$ in $100 \mu \mathrm{l}$ of medium 199 containing $10 \%$ FCS was added to each well, and the cells incubated at $37^{\circ} \mathrm{C}$ for $1.5 \mathrm{~h}$. After two further washes, antibodies ( $\square$, pooled high titer antisera; $\square$, purified anti-hsp65 antibodies; $\square$, pooled low titer sera; $⿴ 囗 十$, unbound Ig fraction; $\square, \mathrm{mAb}$ anti-Factor VIII; $\mathbb{\square}, \mathrm{mAb}$ anti- $\alpha$-actin; $\mathbb{\mathbb { }}$, mAb anti-hsp70; and $\square$, mAb anti-CD3) in $100 \mu \mathrm{l}$ of the medium were added and incubated at $37^{\circ} \mathrm{C}$ for $7 \mathrm{~h}$ in the presence of guinea pig serum. After incubation, supernatant radioactivity was determined in a gamma counter. The values are means of three experiments, each performed in triplicates. ${ }^{*} \mathrm{Sig}$ nificant difference from untreated cells, $P<0.01$.

by several different mechanisms. First, infection with agents that contain hsp proteins homologous to mammalian hsp60 could induce an antiself response through molecular mimicry in susceptible individuals (38). Second, viral infection might result in incorporation of hsp60 into the budding virus, rendering it immunogenic (39). Third, the protein could become immunogenic due to structural alteration or posttranslational modification resulting from metabolic changes or viral infection (40). Fourth, other foreign or self antigens could interact with hsp60 to form immunogenic complexes in which B cells recognize hsp60, and $\mathrm{T}$ cells direct their response to the associated antigen (41). Finally, a bona fide autoimmune reaction to hsp60 might also occur. We hypothesize that the increased levels of hsp65/60 antibodies may be involved in the development of atherosclerosis by a cross-reactive response to lesion proteins or cell components.

In addition to this humoral immune response against hsp65 and the hsp60 homologue, $\mathrm{T}$ cell-mediated immune reactions

Figure 4. Indirect immunofluorescence surface staining of endothelial cells with anti-hsp65 antibodies. Subconfluent endothelial cells were incubated at $42^{\circ} \mathrm{C}$ for $30 \mathrm{~min}(a-i)$ followed by $3 \mathrm{~h}$ at $37^{\circ} \mathrm{C}$ or without initial heat stress $(j, k$, and $l)$. After three washes with medium 199, the living cells were probed with pooled high titer anti-hsp65 antisera $(a-d$, and $j)$, purified anti-hsp65 antibodies $(e-h$, and $k)$, pooled low titer sera $(i$ and $l)$, visualized with a rabbit anti-human Ig-FITC, and examined with a laser confocal microscope. The cell $(a-d$ or $e-h)$ was sectionally scanned in $2-\mu \mathrm{m}$ steps ( $\times 200)$. 
A

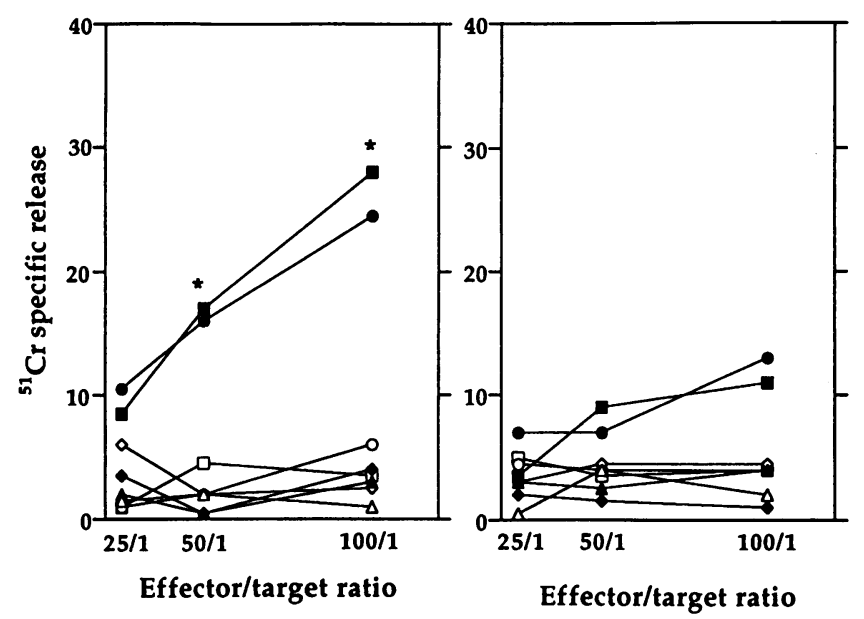

Figure 7. Dose-response curves for ADCC. The procedures for heat stressing and $\mathrm{Ab}$ treatment were the same as described in the legend for Fig. 5. As effectors normal human PBMC were added to the culture instead of complement. Note increased ${ }^{51} \mathrm{Cr}$ release at higher effector/ target cell ratios $(A$, stressed human umbilical vein endothelial cells, $B$, unstressed human umbilical vein endothelial cells). $\square$, pooled high titer antisera; $\bullet$, purified anti-hsp65 antibodies; $\square$, pooled low titer antisera; $O$, unbound Ig fraction; $\Delta, \mathrm{mAb}$ anti-Factor VIII; $\triangle \mathrm{mAb}$ anti- $\alpha$-actin; $\diamond, \mathrm{mAb}$ anti-hsp70; and $\diamond, \mathrm{mAb}$ anti-CD3. ${ }^{*}$ Significant difference from untreated cells, $P<0.01$.

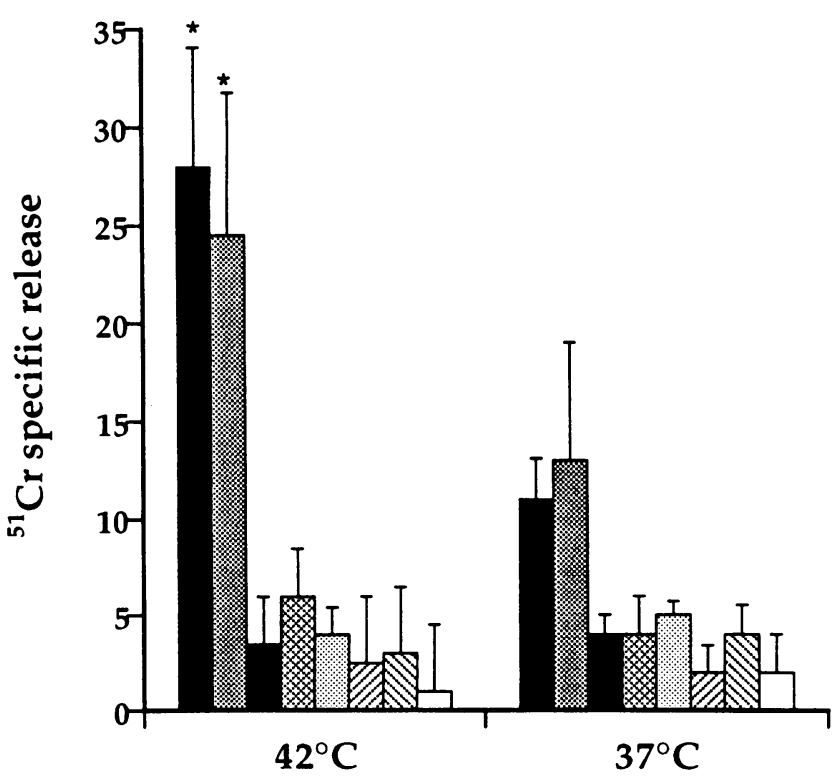

Figure 8. Comparison of ADCC. The procedures for cell stressing and addition of $\mathrm{Ab}$ were the same as described in the legend for Fig. 6 . Human PBMC were added as effectors to the culture in an optimal effector/target ratio $(50: 1)$. $\mathbf{\square}$, pooled high titer antisera; $\mathbf{\square}$, purified anti-hsp65 antibodies; $\mathrm{a}$, pooled low titer sera; $⿴ 囗$, unbound Ig fraction; $\square, \mathrm{mAb}$ anti-Factor VIII; $\square, \mathrm{mAb}$ anti- $\alpha$-actin; $\mathbb{\$}, \mathrm{mAb}$ antihsp70; and $\square, \mathrm{mAb}$ anti-CD3. * Significant difference from untreated cells, $P<0.01$. also occur during atherogenesis. Infiltration of the intima by activated $\mathrm{T}$ cells and macrophages has been shown to represent the earliest changes in atherogenesis (42-45). Compared to peripheral blood, $\mathrm{T}$ cell receptor $\gamma / \delta$-positive lymphocytes have been shown to be enriched in early human atherosclerotic lesions (6). Interestingly, $T$ cells from atherosclerotic lesions of rabbits give strong proliferative responses to hsp65 (5). Whether this is also true for human lesions and whether the cellular or the humoral immune reaction against hsp65 and hsp60 is the possible primary pathogenetic event are currently being studied in our laboratory. However, it remains to be clarified if these early infiltrating lymphocytes exert a proatherogenic function or play a more protective role as is suggested by recent animal data $(46,47)$.

In summary, specific antibodies against hsp60 could react with surface expressed hsp60 components or cross-react with other proteins due to sequence homologies (48) on aortic endothelium, including complement-mediated cell lysis, ADCC, and/or specific T cell-mediated responses (49) to cause endothelial injury and subsequently the development of early lesions. On the other hand, antibodies could pass through the injured endothelium of early stages of the disease and specifically bind hsp60 expressed in high levels on macrophages/foam cells resulting in cell lysis, which may contribute to the formation of the necrotic core in advanced lesions. Studies to elucidate the in vivo role of this potentially pathogenic $\mathrm{Ab}$ are under way.

\section{Acknowledgments}

We thank Dr. R. S. Gupta, Department of Biochemistry, McMaster University, Hamilton, Canada for kindly providing recombinant human hsp60 and Dr. J. D. A. van Emden, National Institute of Public Health and Environmental Protection, The Netherlands, for providing Mycobacterial bovis BCG hsp65 (the production of the hsp65 is supported by the United Nations Development Program/World Bank/World Health Organization Special program for research and training in tropical diseases). We also thank Dr. O. Dapunt, Clinic of Gynecology and Obstetrics, University of Innsbruck, Medical School for providing umbilical cords for endothelial cell culture, Dr. D. Schönitzer, Department of Blood Transfusion, University of Innsbruck, Medical School, for peripheral blood samples from healthy donors, and I. Atzinger for the preparation of photographs.

This work was supported by a grant from the Austrian Research Council (G. Wick, projects No. 8925 and 10677) and an award of the Sandoz Foundation for Gerontological Research (G. Wick).

\section{References}

1. Morimoto, R. I. 1993. Cells in stress: transcriptional activation of heat shock genes. Science (Wash. DC). 259:1409-1410.

2. Young, R. A., and T. J. Elliot. Stress proteins, infection and immune surveillance. 1989. Cell. 59:5-8.

3. Udelsman, R., M. J. Blake, C. A. Stagg, D. Li, D. J. Putney, and N. J. Holbrook. 1993. Vascular heat shock protein expression in response to stress. $J$. Clin. Invest. 91:465-473.

4. Xu, Q., G. Schett, C. S. Seitz, Y. Hu, R. S. Gupta, and G. Wick. 1994. Surface staining and cytotoxic activity of heat shock protein 60 antibody on stressed aortic endothelial cells. Circ. Res. 75:1078-1085.

5. Xu, Q., R. Kleindienst, W. Waitz, H. Dietrich, and G. Wick. 1993. Increased expression of heat shock protein 65 coincides with a population of infiltrating $T$ lymphocytes in atherosclerotic lesions of rabbits specifically responding to heat shock protein 65. J. Clin. Invest. 91:2693-2702.

6. Kleindienst, R., Q. Xu, J. Willeit, F. Waldenberger, S. Weimann, and G. Wick. 1993. Immunology of atherosclerosis: demonstration of heat shock protein 60 expression and T-lymphocytes bearing $\alpha / \beta$ or $\gamma / \delta$ receptor in human atherosclerotic lesions. Am. J. Pathol. 142:1927-1937.

7. Xu, Q., H. Dietrich, H. J. Steiner, A. M. Gown, G. Mikuz, S. H. E Kaufmann, and G. Wick. 1992. Induction of atherosclerosis in normocholestero- 
lemic rabbits by immunization with heat shock protein 65 . Arterioscler. Thromb. 12:789-799.

8. Xu, Q., J. Willeit, M. Marosi, R. Kleindienst, F. Oberhollenzer, S. Kiechl, T. Stulnig, G. Luef, and G. Wick. 1993. Association of serum antibodies to heatshock protein 65 with carotid atherosclerosis. Lancet. 341:255-259.

9. Xu, Q., G. Luef, S. Weimann, R. S. Gupta, H. Wolf, and G. Wick. 1993 Staining of endothelial cells and macrophages in atherosclerotic lesions with human heat-shock protein-reactive antisera. Arterioscler. Thromb. 13:1763-1769.

10. Marder, V. J., P. M. Mannucci, B. G. Firkin, L. W. Hoyer, and D. Meyer. 1985. Standard nomenclature for factor VIII and von Willebrand factor: a recommendation by the International Committee on Thrombosis and Hemostasis. Thromb. Haemostasis. 54:871-872.

11. Chomzcynski, P., and N. Sacchi. 1987. Single-step method of RNA isolation by acid guanidinium thiocyanate-phenol-chloroform extraction. Anal. Biochem. 162:156-159.

12. Dugaiczyk, A., J. A. Haron, E. M. Stone, O. E. Dennison, K. N. Rothblum, and R. J. Schwartz. 1983. Cloning and sequencing of a deoxyribonucleic acid copy of glyceraldehyde-3-phosphate dehydrogenase messenger ribonucleic acid isolated from chicken muscle. Biochemistry. 22:1605-1613.

13. Singh, B., and R. S. Gupta. 1992. Expression of human $60-\mathrm{kD}$ heat shock protein (HSP60 or P1) in Escherichia coli and the development and characterization of corresponding monoclonal antibodies. DNA Cell Biol. 11:489-496.

14. Laemmli, U. K. 1970. Cleavage of structural proteins during the assembly of the head of bacteriophage T4. Nature (Lond.). 227:680-685.

15. Sgonc, R., G. Boeck, H. Dietrich, J. Gruber, H. Recheis, and G. Wick. 1994. Simultaneous determination of cell surface antigens and apoptosis. TIG (Trends Genet.) 10:41-42.

16. Jürgens, G., Q. Xu, L. A. Huber, G. Böck, H. Howanietz, G. Wick, and K. N. Traill. 1989. Promotion of lymphocyte growth by high density lipoproteins (HDL): physiological significance of the HDL binding site. J. Biol. Chem. 264:8549-8556.

17. Salonen, J. T., S. Ylä-Herttuala, R. Yamamoto, S. Butler, H. Korpela, R. Salonen, K. Nyyssönen, W. Palinski, and J. L. Witztum. 1992. Autoantibody against oxidized LDL and progression of carotid atherosclerosis. Lancet. 339:884887.

18. Seifert, P. S., and D. Kazatchkine. 1988. The complement system in atherosclerosis. Atherosclerosis. 73:91-104.

19. Libby, P., and G. K. Hansson. 1991. Involvement of the immune system in human atherogenesis: current knowledge and unanswered questions. Lab. Invest. $64: 5-15$.

20. Muscari, A., C. Bozzoli, C. Gerratana, F. Zaca, C. Rovinetti, D. Zauli, M. La Placa, and P. Puddu. 1988. Association of serum IgA and C4 with severe atherosclerosis. Atherosclerosis. 74:179-186.

21. Hollander, W., M. A. Colombo, B. Kirkpatrick, and J. Paddock. 1979. Soluble proteins in the human atherosclerotic plaque. Atherosclerosis. 38:391398.

22. Vlaicu, R., F. Niculescu, H. G. Rus, and A. Cristea. 1985. Immunohistochemical localization of the terminal C5-b-9 complement complex in human aortic fibrous plaque. Atherosclerosis. 57:163-167.

23. Seifert, P. S., and G. K. Hansson. 1989. Complement receptors and regulatory proteins in human atherosclerotic lesions. Arteriosclerosis. 9:802-810.

24. Seifert, P. S., F. Hugo, G. K. Hansson, and S. Bhakdi. 1989. Prelesional complement activation in experimental atherosclerosis: terminal C5b-9 complement deposition coincides with accumulation in aortic intima of hypercholesterolemic rabbits. Lab. Invest. 6:747-756.

25. Seifert, P. S., F. Hugo, G. Tranum-Jensen, U. Zahringer, M. Muhly, and S. Bhakdi. 1990. Isolation and characterization of a complement-activating lipid extracted from human atherosclerotic lesion. J. Exp. Med 172.547-554.

26. Ylä-Herttuala, S., W. Palinski, S. W. Butler, S. Picard, D. Steinberg, and J. L. Witztum. 1994. Rabbit and human atherosclerotic lesions contain IgG that recognizes epitopes of oxidized LDL. Arterioscler. Thromb. 14:32-40.

27. Jürgens, G., Q. Chen, H. Esterbauer, S. Mair, G. Ledinski, H. P. and Dinges. 1993. Immunostaining of human autopsy aortas with antibodies to modified apolipoprotein B and apoprotein(a). Arterioscler. Thromb. 13:1689-1699.

28. Stemme, S., B. Faber, J. Holm, O. Wiklund, J. L. Witztum, and G. K.
Hansson. 1995. T lymphocytes from human atherosclerotic plaques recognize oxidized low density lipoprotein. Proc. Natl. Acad. Sci. USA. 92:3893-3897.

29. Jindal, S., E. Burke, B. Bettencourt, S. Khandekar, R. A. Young, and D. S. Dwyer. 1994. Human hsp60: bacterial expression, purification, development of monoclonal antibodies and a sandwich ELISA for quantitation. Immunol. Lett. 39:127-135.

30. Evans, D. J., P. Norton, and J. Ivanyi. 1990. Distribution in tissue sections of the human GroEL stress protein homologue. APMIS. 98:437-441.

31. Davies, P. F., A. Remuzzi, E. J. Gordon, C. F. J. Dewey, and M. A. J. Gimbrone. 1986. Turbulent fluid shear stress induces vascular endothelial cell turnover in vitro. Proc. Natl. Acad. Sci. USA. 83:2114-2117.

32. Kiessling, R., A. Grönberg, J. Ivanyi, K. Söderstrom, M. Ferm, S. Kleinau, E. Nilsson, and L. Klareskog. 1991. Role of hsp60 during autoimmune and bacterial inflammation. Immunol. Rev. 12:91-111.

33. Wurttenberg, A. W., B. Schoel, J. Ivanyi, and S. H. E. Kaufmann. 1991. Surface expression by mononuclear phagocytes of an epitope shared with mycobacterial heat shock protein 60. Eur. J. Immunol. 21:1089-1092.

34. Cesare, S. D., F. Poccia, A. Mastino, and V. Colizzi. 1992. Surface expressed heat-shock proteins by stressed or human immunodeficiency virus (HIV)-infected lymphoid cells represent the target for antibody-dependent cellular cytotoxicity. Immunology. 76:341-334.

35. Palinski, W., E. Miller, and J. L. Witztum. 1995 Immunization of low density lipoprotein (LDL) receptor-deficient rabbits with homologous malondialdehyde-modified LDL reduces atherogenesis. Proc. Natl. Acad. Sci. USA. 92:821 825.

36. Shimano, H., N. Yamada, S. Ishibashi, H. Mokuno, N. Mori, T. Gotoda K. Harada, Y. Akanuma, T. Murase, Y. Yazaki, and F. Takaku. 1991. Oxidationlabile subfraction of human plasma low density lipoprotein isolated by ion-exchange chromatography. J. Lipid Res. 32:763-773.

37. Hodis, H. N., D. M. Kramsch, P. Avogaro, G. Bittolo-Bon, G. Cazzolato J. Hwang, H. Peterson, and A. Sevanian. 1994. Biochemical and cytotoxic characteristics of an in vivo circulating oxidized low density lipoprotein (LDL-). $J$. Lipid Res. 35:669-677.

38. Cohen, I. R. 1990. A heat shock protein, molecular mimicry and autoimmunity. Isr. J. Med. Sci. 26:673-676.

39. Zinkernagel, R. M., S. Cooper, J. Chambers, R. A. Lazzarini, H. Hengartner, and H. Arnheiter. 1990 . Virus-induced autoantibody response to a transgenic viral antigen. Nature (Lond.). 345:68-71.

40. Schattner, A., and B. Rager-Zisman. 1990. Virus-induced autoimmunity. Rev. Infect. Dis. 12:204-222.

41. Coulie, P. G., and J. van Snick. 1985. Rheumatoid factor production during anamnestic response in the mouse. J. Exp. Med. 161:88-97.

42. Emeson, E. E., and A. L. Robertson, Jr. 1988. T-lymphocytes in aortic and carotid intimas. Their potential role in atherogenesis. Am. J. Pathol. 130 369-376.

43. Hansson, G. K., L. Jonasson, B. Lojsthed, S. Stemme, O. Kocher, and G. Gabbiani. 1988. Localization of $\mathrm{T}$ lymphocytes and macrophages in fibrous and complicated human atherosclerotic plaques. Atherosclerosis. 72:135-141.

44. Ross, R. 1993. The pathogenesis of atherosclerosis. A perspective for the 1990's. Nature (Lond.). 362:801-809.

45. Xu, Q., G. Oberhuber, M. Gruschwitz, and G. Wick. 1990. Immunology of atherosclerosis: cellular composition and major histocompatibility class II antigen expression in aortic intima, fatty streaks, and atherosclerotic plaques in young and aged human specimen. Clin. Immunol. Immunopathol. 56:344-359.

46. Hansson, G. K., J. Holm, S. Holm, Z. Fotev, H. J. Hedrich, and J. Fingerle. 1991. T-lymphocytes inhibit the vascular response to injury. Proc. Natl. Acad. Sci. USA. 88:10530-10535.

47. Fyfe, A., J. H. Qiao, and A. J. Lusis. 1994. Immune-deficient mice develop typical atherosclerotic fatty streaks when fed an atherogenic diet. J. Clin. Invest. 94:2516-2520.

48. Jones, D. B., A. F. W. Coulson, and G. W. Duff. 1993. Sequence homologies between hsp60 and autoantigens. Immunol. Today 14:115-118.

49. Wick, G., G. Schett, A. Amberger, R. Kleindienst, and Q. Xu. 1994. Is atherosclerosis an immunologically mediated disease? Immunol. Today. 16:2733. 